\title{
P02.10. 10-year experience from an integrative pediatric oncology centre: a retrospective analysis
}

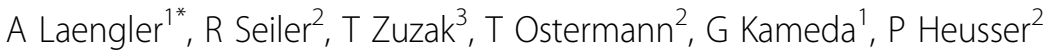 \\ From International Research Congress on Integrative Medicine and Health 2012 \\ Portland, Oregon, USA. 15-18 May 2012
}

\section{Purpose}

Complementary and alternative therapies (CAM) are widely used in pediatric oncology. Till now there are no published data on the clinical practice of integrating CAM into standard pediatric oncology (PO) care.

\section{Methods}

We performed a retrospective analysis of patient records of all PO-patients treated in our integrative pediatric oncology centre (IPOC) with 1st admission between January $1^{\text {st }} 1999$ and December $31^{\text {st }}$ 2008. Inclusioncriteria were: age 0-18 years; proven cancer-diagnosis; and at least one conventional intervention (chemotherapy, operation, radiation) in our hospital.

\section{Results}

A total of 116 cases (39\% female) were analysed. Seventy-eight percent were admitted with their $1^{\text {st }}$ cancer-diagnosis, $22 \%$ with any relapse. Fifty-eight percent received their diagnosis in our hospital, $42 \%$ in another hospital (9\% of them outside Germany). The spectrum of diagnosis was the same as in the German PO-population. Along with a standard conventional therapy according to actual treatment-plans within the GPOH- and/or SIOP-framework, 91\% of our patients received some form of CAM-medication (e.g. 75\% mistletoe-preparations), most out of the spectrum of Anthroposophic Medicine (AM). We could identify a Top 10 of AM remedies prescribed to most patients. The most used nonpharmacological CAM-interventions were: $63 \%$ eurythmy therapy, $56 \%$ art-therapies (painting, sculpturing), 51\% music therapy, $46 \%$ external embrocations and compresses. There were no reported serious adverse events for

${ }^{1}$ Centre for Integrative Pediatric Oncology Gemeinschaftskrankenhaus, Herdecke, Germany

Full list of author information is available at the end of the article any of the pharmacological or non-pharmacological CAM interventions.

\section{Conclusion}

It is possible to integrate CAM into an IPOC within the standard-spectrum of $\mathrm{PO}$-diseases. In a retrospective analysis over a 10-year-period we found no indices for relevant toxicities. Statements regarding the effectiveness of this approach cannot be drawn from this retrospective analysis. Further prospective studies of this approach are necessary.

\section{Author details}

${ }^{1}$ Centre for Integrative Pediatric Oncology Gemeinschaftskrankenhaus, Herdecke, Germany. ${ }^{2}$ Witten Herdecke University, Witten, Germany.

${ }^{3}$ University of Essen Pediatric Oncology, Essen, Germany.

Published: 12 June 2012

doi:10.1186/1472-6882-12-S1-P66

Cite this article as: Laengler et al.: P02.10. 10-year experience from an integrative pediatric oncology centre: a retrospective analysis. $B M C$ Complementary and Alternative Medicine 2012 12(Suppl 1):P66.

Submit your next manuscript to BioMed Central and take full advantage of:

- Convenient online submission

- Thorough peer review

- No space constraints or color figure charges

- Immediate publication on acceptance

- Inclusion in PubMed, CAS, Scopus and Google Scholar

- Research which is freely available for redistribution
C Biomed Central

() 2012 Laengler et al; licensee BioMed Central Ltd. This is an Open Access article distributed under the terms of the Creative Commons Attribution License (http://creativecommons.org/licenses/by/2.0), which permits unrestricted use, distribution, and reproduction in any medium, provided the original work is properly cited. 